OLIVEIRA, SI; RIBEIRO, EH; MOREIRA, NF; VIANNA, LS; PEREIRA, TNS. 2020. Meiotic behavior and fertility of Capsicum interspecific hybrids. Horticultura Brasileira 38: 382-386. Doi: http://dx.doi.org/10.1590/s0102-0536202004007

\title{
Meiotic behavior and fertility of Capsicum interspecific hybrids
}

\author{
Sara I de Oliveira ${ }^{1} \mathbb{D}$; Elba H Ribeiro ${ }^{1} \mathbb{D}$; Nádia F Moreira ${ }^{1} \mathbb{D}$; Larissa S Vianna ${ }^{1} \mathbb{D}$; Telma NS Pereira ${ }^{1} \mathbb{D}$ \\ ${ }^{1}$ Universidade Estadual do Norte Fluminense Darcy Ribeiro (UENF), Campos dos Goytacazes-RJ, Brasil; telmasp@uenf.br; sarasilvabio2@ \\ gmail.com; elba_hr@hotmail.com; nadia.fernandesm@gmail.com; larissasouzav@hotmail.com
}

\begin{abstract}
This study was performed to evaluate the meiotic behavior and fertility of four hybrids obtained from the crossing of Capsicum baccatum and its botanical forms with Capsicum chinense and Capsicum frutescens. We aimed to identify the causes of the low fertility in interspecific hybrids involving species from different gene pools of Capsicum. Hybrid flower buds were fixed in fixative solution and the slides were prepared using $1 \%$-acetic carmine solution. Meiosis was observed in all phases and the main meiotic abnormality observed was the complete or partial lack of chromosome pairing, indicating that the species are either genetically distant or that some asynaptic gene was present in the hybrids. Meiotic index (MI), the frequency of unreduced gametes (type 2n), and pollen viability were estimated. MI and pollen viability of the hybrids were low. We concluded that due to the complete or partial lack of chromosome pairing, the species used in the hybrid combinations are genetically distant. We also noticed that the low-fertility hybrids are a consequence of the lack of chromosome homology between the two genomes involved. The hybrids were considered partially sterile since their pollen viability percentage was lower than $50 \%$.
\end{abstract}

Keywords: Capsicum baccatum, Capsicum chinense, Capsicum frutescens, meiosis, meiotic abnormality, chromosome pairing.

\section{RESUMO}

Comportamento meiótico e fertilidade de híbridos interespecíficos de Capsicum

Esta pesquisa teve o objetivo de estudar o comportamento meiótico e a fertilidade de quatro híbridos, obtidos do cruzamento entre acessos das espécies Capsicum baccatum e suas formas botânicas com Capsicum chinense e Capsicum frutescens, afim de identificar as possíveis causas da baixa fertilidade observada em híbridos interespecíficos envolvendo espécies pertencentes a diferentes complexos gênicos de Capsicum. Para tal, botões florais dos híbridos foram fixados em solução fixadora e as lâminas foram preparadas utilizando carmim acético a $1 \%$. A meiose foi observada e a principal anormalidade registrada foi a falta total ou parcial de pareamento dos cromossomos indicando que as espécies ou são distantes geneticamente ou algum gene assináptico se manifestou no híbrido. Foram estimados o índice meiótico (IM), a frequência de gametas não reduzidos (tipo 2 n), e a viabilidade polínica. O IM e a viabilidade polínica dos híbridos foram baixos. Conclui-se que, devido à falta total ou parcial de pareamento dos cromossomos, as espécies utilizadas nas combinações híbridas, são distantes geneticamente, e que a baixa fertilidade dos híbridos é consequência dessa falta de homologia entre os cromossomos dos dois genomas envolvidos. Os híbridos podem ser considerados parcialmente estéreis pois a sua viabilidade polínica foi inferior a $50 \%$.

Palavras-chave: Capsicum baccatum, Capsicum chinense, Capsicum frutescens, meiose, irregularidade meiótica, pareamento de cromossomos.

\section{Received on September 24, 2019; accepted on August 3, 2020}

$\mathrm{D}$ espite having several species, the genus Capsicum, green peppers and chili consist of only five domesticated species: Capsicum annuum, Capsicum chinense, Capsicum frutescens, Capsicum baccatum and Capsicum pubescens (Moscone et al., 2007). Domesticated Capsicum species are, preferably, autogamous with hermaphrodite flowers, showing $2 \mathrm{n}=2 \mathrm{x}=24$ chromosomes, but some wild species, showing $2 \mathrm{n}=2 \mathrm{x}=26$ chromosomes (Pozzobon et al., 2006).

The species of Capsicum genus are grouped into three gene pools, according to their crossability and fertility of the obtained hybrids. $C$. annuum complex consists of $C$. annuum, C. chinense, $C$. frutescens, $C$. chacoense and $C$. galapagoense; C. baccatum complex consists of $C$. baccatum var. baccatum, C. baccatum var. pendulum, and C. praetermissum and C. pubescens complex shows some wild species. $C$. pubescens is the only cultivated species, though (Pickersgill, 1991; Zijlstra et al.,1991).

Interspecific hybrids are obtained if the crossing involves species of the same complex (Pickersgill, 1991). According to literature, sometimes hybrids are obtained between Capsicum species which belong to different gene pools; however, these hybrids are sterile or show very low pollen fertility (Egawa \& Tanaka, 1986; Yoon et al., 2006; Manzur et al., 2015) which prevents or hinders gene transfer. This hybrid infertility is explained by the low pollen viability of the obtained combinations, which is due to the genetic distance between the species participating in crossing. The closer the species genetically involved in obtaining the hybrid, the greater the chance to obtain a viable or fertile hybrid (Singh, 2016).

Evaluating meiosis and fertility of a specific obtained hybrid is, 
among several analyses, a way to study chromosomal homology between two species (Singh, 2016), mainly concerning the genomic homology. Cytogenetic analysis is one of the tools used to analyze chromosomal or genomic homology, through meiosis analysis and consequent hybrid fertility. If no chromosomal homology between parents is noticed, chromosome pairing in interspecific hybrids will be impaired and the gene transfer between species will not occur, as no pairing between chromosomes will be verified, no crossing will occur (Brambatti et al., 2016).

The aim of this study was to evaluate the meiotic behavior and fertility of four hybrids obtained between $C$. baccatum var pendulum and $C$. chinense; $C$. baccatum var. pendulum and $C$. frutescens; C. baccatum var baccatum and $C$. chinense; and $C$. baccatum var. baccatum and $C$. frutescens in order to clarify the reasons for the low fertility of interspecific Capsicum hybrids reported in literature.

\section{MATERIAL AND METHODS}

\section{Plant material}

In this study, we used four interspecific hybrids obtained from the crossing between the following species: C. baccatum var pendulum and $C$. chinense (UENF $1496 \times$ UENF 1785); C. baccatum var. pendulum and C. frutescens (UENF 1624 x UENF 1636); C. baccatum var. baccatum and $C$. chinense (UENF $1495 \times$ UENF 1785 ) and C. baccatum var. baccatum and $C$. frutescens (UENF 1495 x UENF 1636) obtained in breeding program at Universidade Estadual do Norte Fluminense (Oliveira, 2019).

Hybrid seeds and parents were sown in styrofoam trays, filled with commercial vegetal substrate Vivatto®. After one month, the seedlings were transferred into 300-mL plastic cups containing the same vegetal substrate. The material was kept in this container for one month, then we transferred the plantlets into 5-liter pots and kept them in a greenhouse. The experimental design was completely randomized, with three replicates. Each replicate consisted of four plots (hybrid combination), each combination was represented by five pots with one plant per pot, totalizing five plants. Cultural practices were performed according to the necessity of the plant and according to the recommendations proposed by Filgueira (2008).

\section{Meiotic analysis}

In order to evaluate the meiotic behavior of the hybrids, flower buds, in different development stages, were collected and fixed in an ethanol solution: acetic acid, at a 3:1 ratio, for 24 hours. After, the buds were transferred to the $70 \%$ ethanol solution and kept in the refrigerator. The microscope slides were prepared according to the squash method: three anthers of each bud were squashed in drops of $1 \%$ acetic carmine. After removing the debris, the material was covered with a coverslip and the slides were observed under an optical microscope (Olympus BX60). The analysis of prophase I was prioritized in order to observe the pairing of chromosomes in hybrids and the images were captured with the aid of the Software CellSens Standard 1.8 (Olympus).

In order to estimate the meiotic index (IM) (Love, 1951) and to estimate the frequency of unreduced gametes (Yan et $a l ., 1997)$, three anthers were macerated in drops of $1 \%$ acetic carmine, and five slides per hybrid were prepared. We counted 400 post-meiotic products/ slides, totalizing 2000 post-meiotic products, for each estimate.

Hybrid fertility was estimated via pollen viability test. Floral buds at anthesis were collected, kept in $70 \%$ ethanol solution, in a freezer at $4^{\circ} \mathrm{C}$. For preparing the slides, the authors macerated the anthers in a drop of triple Alexander solution (Alexander, 1969). For each hybrid, five slides were prepared. In each slide, 400 pollen grains were counted, totalizing 2000 pollen grains. Purple-colored pollen grains were considered viable and green-colored pollen grains were considered non-viable. All slides were observed under an optical microscope
(Olympus BX60), images were captured using CellSens Standard 1.8 (Olympus). Pollen viability data were submitted to analysis of variance using the Genes software (Cruz, 2013).

\section{RESULTS AND DISCUSSION}

The authors observed that, in hybrid meiosis, the vast majority of cells analyzed in Prophase I presented unpaired chromosomes or part paired chromosomes and part univalent chromosomes (Figure 1). Hybrids UENF 1496 x UENF 1785 and UENF 1624 x UENF 1636 (Figures 1A and 1B), whose pollen receptor accession was $C$. baccatum var pendulum (UENF 1496 and UENF 1624), showed complete lack of chromosome pairing, indicating a lack of homology among the genomes of this species, belonging to $C$. baccatum complex, with pollen donator species (C. chinense and C. frutescens), both belonging to $C$. annuum complex. Another reason for the lack of pairing can be due to the presence of a synaptic gene in the genome of the parental species of the hybrid. Synaptic genes are genes which affect the normal chromosome pairing (Wani \& Bhat, 2017). They can be asynaptic genes which can cause a complete lack of chromosome pairing during Prophase I, or desynaptic genes which cause a pairing at the beginning of Prophase I, failing to maintain this association in the subsequent stages and, thus, separate prematurely (Wani \& Bhat, 2017). If no pairing is verified, no crossingover between non-sister chromatids occurs and, consequently, a failure in the introgression of genes is verified (Singh, 2016).

On the other hand, the authors also observed that hybrids whose female parent was the accession UENF 1495 (C. baccatum var. baccatum) showed some paired chromosomes, being possible to verify some bivalent and univalent ones (Figure 1C and 1D). Some cytogenetic studies on hybrids of C. baccatum $x$ C. frutescens reported that, in both F1 and F2, the hybrids presented irregular meiosis, with an association of eight bivalent and one 
quadrivalent chromosomes (Rao et al., 1992). One study indicated the possibility of using $C$. chinense as a bridge species in crossings involving $C$. baccatum species, aiming at posterior crossing of the hybrid with $C$. annuum. There was success in using it as a bridge species, so the crossing is indicated (C. baccatum $\mathrm{x} C$. chinense $) \times(C$. annuum). Nevertheless, $C$. frutescens was not considered an effective bridge species when the goal was to $\operatorname{transfer} C$. frutescens genes to C. annuum (Manzur et al., 2015). Thus, this combination $C$. baccatum $\times$ C. chinense can be a good alternative to transfer the $C$. baccatum genes, since $C$. chinense species shows average crossability with the cultivated form (Martins et al., 2015).

Many irregularities have been observed, such as lagging chromosomes, as a consequence of lack of pairing observed in hybrids. The presence of lagging chromosomes can generate unbalanced or aneuploid gametes, due to the possibility of being trapped in the cytoplasm, not following the set of chromosomes which follow cell division normally, and in the end, be eliminated in the form of micronuclei (Figure 1E) (Kodoru \& Rao, 1981; Pozzobon et al., 2011).

In this study, the meiotic index, a complementary data in the meiotic analysis and an indicator of regularity (Love, 1951), was estimated for the four hybrid combinations. The hybrids which showed $C$. chinense as male parent (UENF $1496 \times$ UENF 1785 and UENF 1495 X UENF 1785) showed meiotic indexes of $58.50 \%$ and $55.25 \%$, respectively. Whereas the hybrids which showed $C$. frutescens as male parent (UENF 1495 x UENF 1636 and UENF 1624 x UENF 1636) showed meiotic indexes of $60.4 \%$ and $64.3 \%$, respectively. Genotypes with meiotic indexes inferior to $90 \%$ showed low meiotic stability, which can cause reproductive problems when used in crossings, as they are considered cytologically unstable. Thus, we can state that the hybrids analyzed in this study presented low meiotic stability (Love, 1951).

The authors observed some dyads (Figure 1E), triads (Figure 1F and $1 \mathrm{G}$ ) which generated as a consequence unreduced gametes in a frequency which ranged from $6.05 \%$ in UENF $1496 \mathrm{x}$ UENF 1785 to $13.2 \%$ in UENF 1495 $x$ UENF 1636. Unreduced gametes, type $2 \mathrm{n}$, resulted from an abnormal meiotic process, in which no reduction in chromosome number is verified. This failure in reduction may occur due to the restitution in the first division (RFD) when in meiosis I, chromosomes do not move to the poles during anaphase I and, instead of two cells with haploid number of chromosomes in telophase I, the formation of a cell with diploid number is noticed. In this case, meiosis II occurs normally, resulting in a dyad instead of triad, though (which was already expected). This division (RFD) occurs when the plants in which pairing between homologues or homeologues (interspecific hybrids) is completely absent as in synaptic mutants or distant hybrids and in plants whose cytokinesis is of the successive type as is the case of most dicots (Schifino-Wittmann \& Dall'Agnol, 2001; Ramanna \& Jacobsen, 2003). The other way to form $2 \mathrm{n}$ gametes is in meiosis II, by the restitution in the second division (RSD), in which a cytokinesis failure and diploid restitution nucleus (with formation of dyads or triads) can be verified (Ramanna \& Jacobsen, 2003). Unreduced gametes occur spontaneously in virtually all natural plant populations but, in general, in very low percentages, around $1 \%$ or less (Schifino-Wittmann \& Dall'Agnol, 2001). According to literature, frequency of unreduced male gametes in hybrids was 50 times higher $(27.52 \%)$ than in non-hybrids $(0.56 \%)$ (Ramsey \& Schemske, 1998). However, in this study, the frequency of triads (Figures $1 \mathrm{~F}$ and $1 \mathrm{G}$ ) was average, which

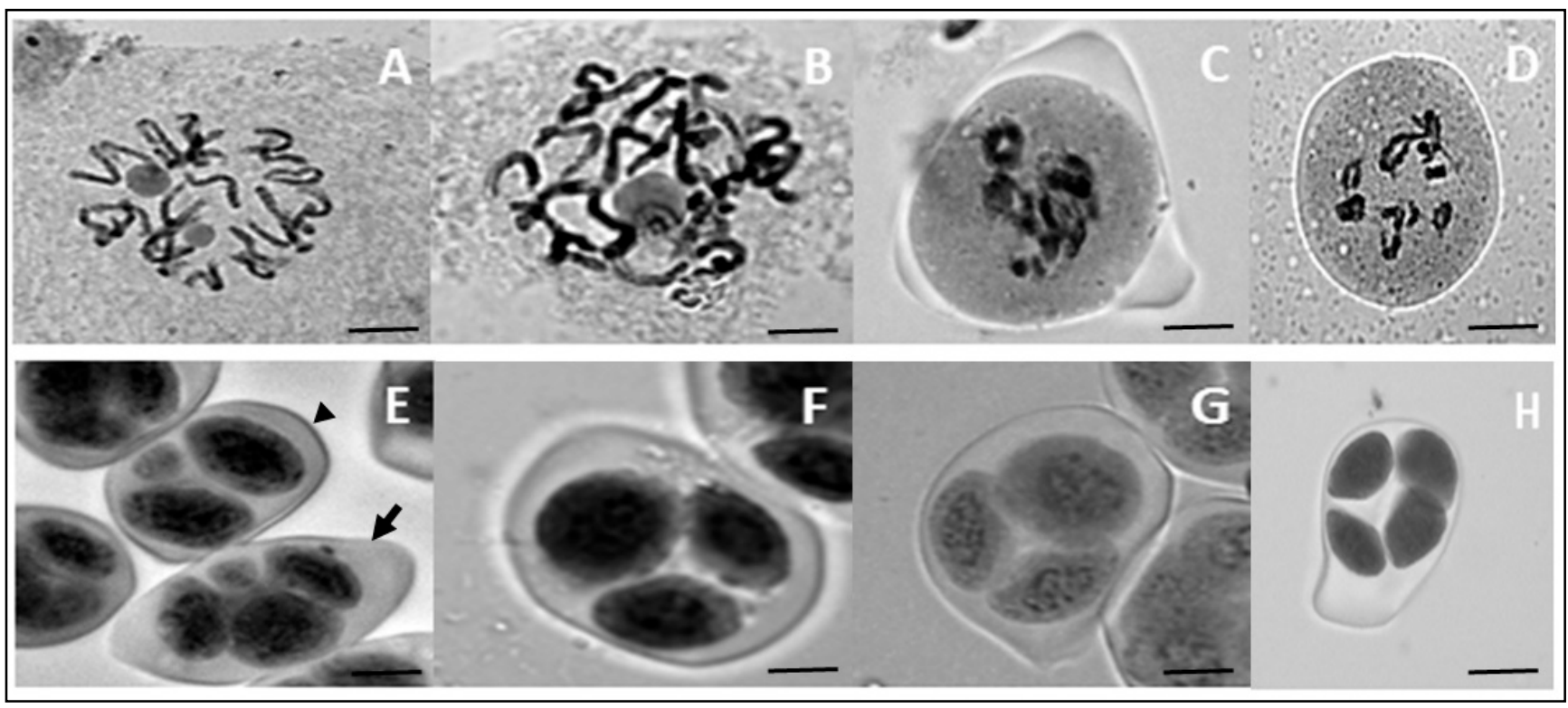

Figure 1. A-D) Chromosomal pairing in Prophase $\mathrm{I}$ in interspecific hybrids; $\mathrm{A}$ and $\mathrm{B}=$ lack of chromosome pairing; $\mathrm{C}$ and $\mathrm{D}=$ partial chromosome A) UENF 1496 x UENF 1785; B) UENF 1624 x UENF 1636; C) UENF 1495 x UENF 1636; and D) UENF 1495 x UENF 1785. E-F) Pos-meiotic products. $\mathrm{E}=$ dyad (arrow head) and triads (arrow) with micronuclei; $\mathrm{F}$ and $\mathrm{G}=$ triads; $\mathrm{H}=$ tetrads. $\mathrm{Bar}=20 \mu \mathrm{m}$. Campos dos Goytacazes, UENF, 2019. 

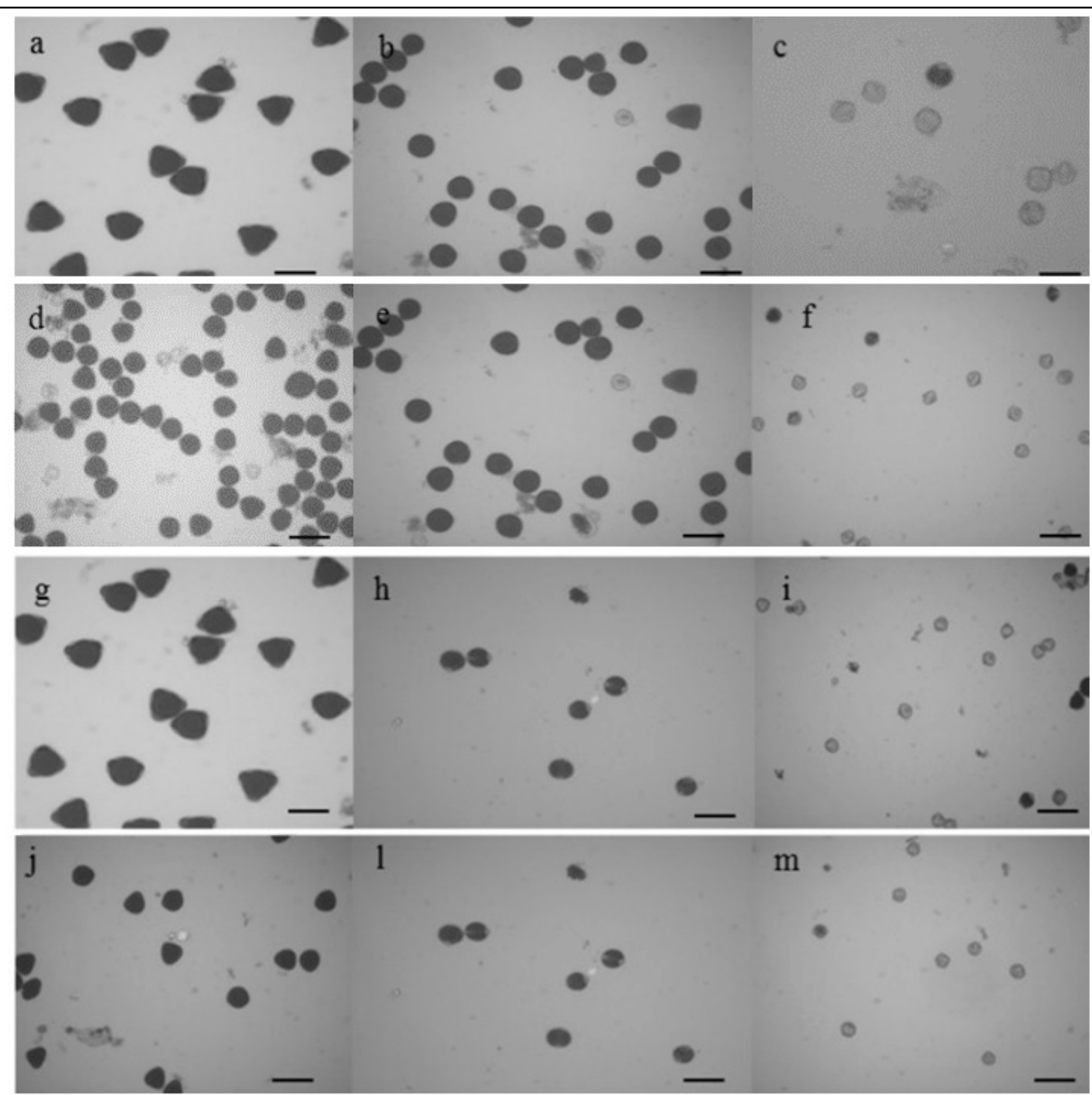

Figure 2. Viable (a, b, d, e, g, h, j, and l) and non-viable (c, f, i, and m) pollen grains of parents and interspecific hybrids a= UENF 1495, $\mathrm{b}=$ UENF 1636, c= UENF 1495 x UENF 1636, d= UENF 1624, e= UENF 1636, f= UENF $1624 \times$ UENF 1636, g= UENF 1495, h= UENF 1785, $\mathrm{i}=$ UENF 1495 x UENF 1785, $\mathrm{j}=$ UENF 1496, l= UENF 1785, $\mathrm{m}=$ UENF 1496 x UENF 1785. Bar=20 $\mu \mathrm{m}$. Campos dos Goytacazes, UENF, 2019.

generated some viable pollen grains.

Hybrid fertility was tested using pollen viability (Figure 2). Variance analysis did not verify any significant differences between the pollen viability values of hybrids. In hybrid UENF $1496 \times$ UENF 1785 the value was $34.85 \%$ and in hybrid UENF $1495 \mathrm{x}$ UENF 1785 was $27.05 \%$, inferior to the values obtained for the accession, male parent UENF 1785, whose estimate was $92.85 \%$. In hybrids UENF 1495 $x$ UENF 1636 , pollen viability was $20.95 \%$ and for UENF $1624 \times$ UENF 1636 was $17.95 \%$, estimates inferior when compared with male parent, which showed viability of $69 \%$ for UENF 1636 (C. frutescens). The low viability obtained in hybrids was relatively expected due to unbalanced gametes resulting from meiotic irregularities observed in this study, showing a partial sterility. The hybrid fertility between Capsicum species has been studied and low pollen viability has been estimated for combinations like $C$. baccatum var. pendulum $\times$ C. chinense (25\%) and for $C$. baccatum var. pendulum $\mathrm{x} C$. frutescens (46\%) (Monteiro et al., 2011). Using the estimates of pollen viability, the authors could infer the hybrid fertility, which in this study was partial, considering that the viability was lower than $50 \%$, due to lack of homology between the chromosomes of species involved in the crossing, probably in relation to the genetic distance between them (Pickersgill, 1997).

Despite the partial fertility found in the obtained hybrids, these hybrids can be used as pollen receptors, that is, female parents in backcross breeding programs (Yoon et al., 2006), or they can be used as bridge species in breeding programs to improve the cultivated 
species (Manzur et al., 2015). Thus, further studies would be welcomed to help out breeders establish breeding programs on the cultivated form, using interspecific hybridization as a viable methodology.

\section{ACKNOWLEDGEMENTS}

The authors thank CAPES (Coordination of Improvement of Higher Education Personnel), Brazil, for supporting this study, financing code 001 .

\section{REFERENCES}

ALEXANDER, MP. 1969. Differential staining of aborted and non aborted pollen. Biotechnic and Histochemestry 44: 117-122.

BRAMBATTI, A; BRAMMER, SP; WIETHOLTER, P; NASCIMENTO JUNIOR, A. 2016. Estabilidade genética em triticale estimada pela viabilidade polínica. Arquivos do Instituto Biológico 83: 1-7.

CRUZ, CD. 2013. Genes: a software package for analysis in experimental statistics and quantitative genetics. Acta Scientiarum, Agronomy 35: 271-276.

EGAWA, Y; TANAKA, M. 1986. Cytogenetical study of the interspecific hybrid between Capsicum annuum and C. baccatum. Japanese Journal of Breeding 36: 16-21.

FILGUEIRA, FAR. 2008. Novo manual de olericultura. Viçosa: UFV. 421p.

KODORU, PRK; RAO, MK. 1981. Cytogenetics of synaptic mutants in higher plants. Theoretical Applied Genetics 59: 197-214.
LOVE, RM. 1951. Varietal differences in meiotic chromosomes behavior of Brazilian wheats. Agronomy Journal 43: 72-76.

MANZUR, JP; FITA, A; PROHENS, J; RODRIGUEZ-BURRUEZO, A. 2015. Successful wide hybridization and introgression breeding in a diverse set of common peppers (Capsicum annnuum) using different cultivated ají (C. baccatum) accessions as donor parents. Plos One 10: e0144142.

MARTINS, KC; PEREIRA, TNS; SOUZA, SAM; RODRIGUES, R; AMARAL JÚNIOR, AT. 2015. Crossability and evaluation of incompatibility barriers in crosses between Capsicum species. Crop Breeding and Applied Biotechnology 15: 139-145.

MONTEIRO, CES; PEREIRA, TNP; CAMPOS, KP. 2011. Reproductive characterization of interspecific hybrids among Capsicum species. Crop Breeding and Applied Biotechnology 11: 241-249.

MOSCONE, EA; SCALDAFERRO, MA; GRABIELE, M; CECCHINI, NM; GARCÍA, YS; JARRET, R; DAVIÑA, JR; DUCASSE, DA; BARBOZA, GE; EHRENDORFER, F. 2007. The evolution of chili peppers (Capsicum - Solanaceae): a cytogenetic perspective. Acta Horticulturae 745:137-169.

OLIVEIRA, SI. 2019. Caracterização morfoagronômica e análise citogenética de hibridos interespecificos de Capsicum. Campos dos Goytacazes: UENF. 67p. (M.Sc. dissertation).

PICKERSGILL, B. 1991. Cytogenetics and evolution of Capsicum L. In: TSUCHIYA, T; GUPTA, PK (eds). Chromosome engineering in plants: genetics, breeding, evolution, part B, Amsterdam: Elsevier. p.139-160.

PICKERSGILL, B. 1997. Genetic resources and breeding of Capsicum spp. Euphytica 96: 129-133.

POZZOBON, MT; SCHIFINO-WITTMANN, MT; BIANCHETTI, LB. 2006. Chromosome numbers in wild and semidomesticated
Brazilian Capsicum L. (Solanaceae) species: do $\mathrm{x}=12$ and $\mathrm{x}=13$ represent two evolutionary lines? Botanical Journal of the Linnean Society 151: 259-269.

POZZOBON, MT; SOUZA, KRR; CARVALHO, SIC; REIFSCHNEIDER, FJB. 2011. Meiose e viabilidade polínica em linhagens avançadas de pimenta. Horticultura Brasileira 29: 212-216.

RAMANNA, MS; JACOBSEN, E. 2003. Relevance of sexual polyploidization for crop improvement - a review. Euphytica 133: 3-18.

RAMSEY, J; SCHEMSKE, DW. 1998. Pathways, mechanisms, and rates of polyploidy formation in flowering plants. Annual Review Ecology and Systematics 29: 467-501.

RAO, NB; VALLI, TS; LAKSHMI, N. 1992. Cytogenetic studies on the interspecific hybrid $C$. baccatum L. x C. frutescens L. and its progeny. Euphytica 59: 135-140.

SCHIFINO-WITTMANN, MT; DALL'AGNOL, M. 2001. Gametas não reduzidos no melhoramento de plantas. Ciência Rural 31: 169-175.

SINGH, RJ. 2016. Plant cytogenetics. Boca Raton, USA: CRC Press. 391p.

WANI, AA; BHAT, TA. 2017. Asynapsis and desynapsis in plants. In: BHAT, TA; WANI, AA (eds). Chromosome structure and aberrations. Índia: Springer. p.127-141.

YAN, G; FERGUSON, AR; Mc NEILAGE, MA. 1997. Numerically unreduced $(2 n)$ gametes and sexual polyploidization in Actinidia. Euphytica 96: 267-272.

YOON, JB; YANG, DC; WAHHNG, JD; PARK, HG. 2006. Overcoming two post-fertilization genetic barriers in interspecific hybridization between $C$. annuum $\mathrm{L}$. and $C$. baccatum $\mathrm{L}$. for introgression of Anthracnose resistance. Breeding Science 56: 31-38.

ZIJLSTRA, S; PURIMAHUA, C; LINDHOUT, P. 1991. Pollen tube growth in interspecific crosses between Capsicum species. HortScience 26: 585-586. 